\title{
北陸新幹線・新北陸トンネル工事現場見学会報告+
}

陳 友晴*

\section{Report on Field Trip of Hokuriku Shinkansen Shin-Hokuriku Tunnel Construction Site}

by

\section{Youqing CHEN*}

2017 年 5 月 22 日，北陸新幹線新北陸トンネルの工事 現場において, 平成 29 年度岩石力学部門委員会現場見 学会を開催した。本部門委員会では, 委員と現場技術 者との交流や技術的な問題の討論を通し，岩石力学分 野の発展に資するため, 年に 1 回程度, 現地における 見学会・討論会を企画している.

北陸新幹線は，平成 34 年度末に金沢 - 敦賀間の開業 を目指し工事が進められているが, 新北陸トンネルは, その間の南越（仮称）駅から敦賀駅間で主経路となる 全長約 $19.7 \mathrm{~km}$ の山岳トンネルである. 独立行政法人鉄 道建設・運輸施設整備支援機構 大阪支社が発注者とな り，工事が進められている.

見学会では，まず鉄道建設・運輸施設整備支援機構 の敦賀鉄道建設所（敦賀市）において, 工事概要の説 明を受けた。トンネルはNATM工法で施工されており， 掘削方式は発破掘削方式, 掘削工法は全断面工法また は補助ベンチ付き全断面工法であること, 主たる地質 は, 中古生代の堆積岩 (砂岩, 粘板岩, チャート) と 貫入岩（花崗岩とひん岩）であること, 途中で 2 本の 活断層帯（柳ヶ瀬断層群とウツロギ断層）と交差する ことが予想されていることなどが説明された。また， 掘削後には, インバートコンクリート, 覆工コンクリー 卜，そして軌道構造を支える路盤鉄筋コンクリートと 順次施工していき，新幹線トンネルとして仕上がって いくことが説明され, 工事での安全確保についての取 り組みなどが紹介された，掘削は，本坑に加えて斜坑 を 5 力所設置し，6工区に分けて工事を進める計画であ り，見学会では，すでに本坑を掘削中である葉原工区 と斜坑の掘削を行っている田尻工区を実地に見学させ ていただいた.

葉原工区では，本坑の掘削現場を自動車と徒歩で見 学させていただいた。切羽（掘削中の断面）から順に, 掘削後の支保工施工箇所，インバートコンクリート施 工箇所, FILMによる防水工施工箇所, そして覆工コン クリート施工箇所と施工順序が分かるようになってい た. 工事は, 安全と効率について考えられ, 非常にシ ステマチックに進められていることが観察され (図 1), 興味深いものであった。
また，田尻工区では，斜坑を掘削している現場につ いて見学させていただき, 掘削機や切羽の状況につい ても間近で観察することができた。 また，これまで掘 削してきた岩石の標本等を見ながら，地質や工法の詳 細な説明等を行っていただき，見学者の多様な疑問に もお答えいただいた。

見学会の開催にあたり，鉄道建設・運輸施設整備支 援機構 敦賀鉄道建設所 高原英彰所長, 鎌田和孝主任を はじめ工事関係者の皆様にお世話になりました。ここ に記して謝意を表します。今後の工事の安全を見学者 一同祈念しております。

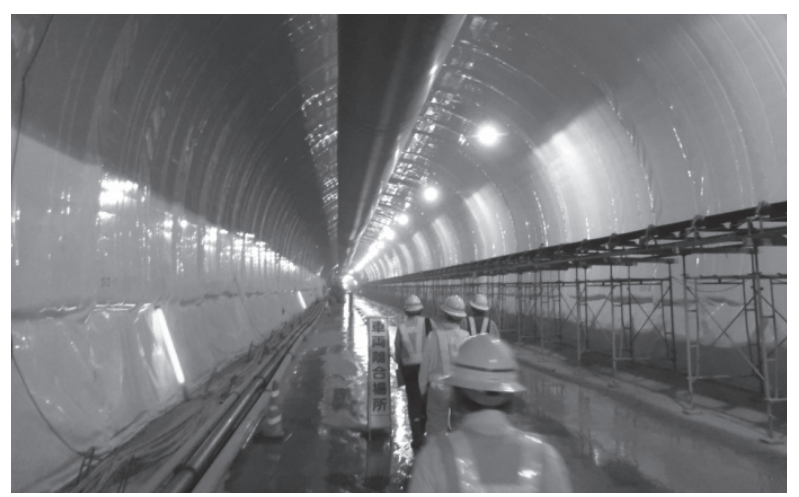

図 1 トンネル内の見学の様子. FILM工法による防水シートが 整然と施工されている，写真右手に見えるのが，ズリを運 び出すためのベルトコンベア.

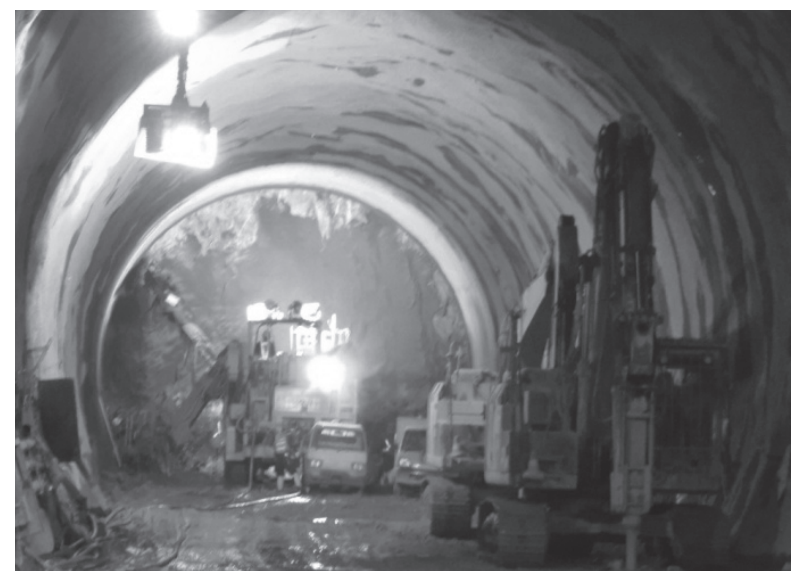

図 2 葉原工区の切羽(掘削中の断面) 周辺状況

原稿受理 平成 29 年 7 月 14 日 Received July 14, 2017 C2017 The Society of Materials Science, Japan

* 正 会 員 京都大学大学院エネルギー科学研究科 ＝ 606-8501 京都市左京区吉田本町, Graduate School of Energy Science, Kyoto University, Sakyo-ku, Kyoto, 606-8501 